Review

\title{
Biological Control of Citrus Postharvest Phytopathogens
}

\author{
Jaqueline Moraes Bazioli ${ }^{1,2}$, João Raul Belinato ${ }^{1}$, Jonas Henrique Costa ${ }^{1}$, \\ Daniel Yuri Akiyama ${ }^{1}$, João Guilherme de Moraes Pontes ${ }^{1} \mathbb{D}$, Katia Cristina Kupper ${ }^{3}$ (D), \\ Fabio Augusto ${ }^{1}$ (D) João Ernesto de Carvalho ${ }^{2}$ and Taícia Pacheco Fill ${ }^{1 \text {,* }}$ \\ 1 Institute of Chemistry, Universidade Estadual de Campinas, CP 6154, 13083-970 Campinas, SP, Brazil \\ 2 Faculty of Pharmaceutical Sciences, Universidade Estadual de Campinas, 13083-859 Campinas, SP, Brazil \\ 3 Instituto Agronômico de Campinas (IAC), 13490-970 Cordeiropolis, SP, Brazil \\ * Correspondence: taicia@iqm.unicamp.br; Tel.: +55-19-3521-3092
}

Received: 11 July 2019; Accepted: 25 July 2019; Published: 6 August 2019

\begin{abstract}
Citrus are vulnerable to the postharvest decay caused by Penicillium digitatum, Penicillium italicum, and Geotrichum citri-aurantii, which are responsible for the green mold, blue mold, and sour rot post-harvest disease, respectively. The widespread economic losses in citriculture caused by these phytopathogens are minimized with the use of synthetic fungicides such as imazalil, thiabendazole, pyrimethanil, and fludioxonil, which are mainly employed as control agents and may have harmful effects on human health and environment. To date, numerous non-chemical postharvest treatments have been investigated for the control of these pathogens. Several studies demonstrated that biological control using microbial antagonists and natural products can be effective in controlling postharvest diseases in citrus, as well as the most used commercial fungicides. Therefore, microbial agents represent a considerably safer and low toxicity alternative to synthetic fungicides. In the present review, these biological control strategies as alternative to the chemical fungicides are summarized here and new challenges regarding the development of shelf-stable formulated biocontrol products are also discussed.
\end{abstract}

Keywords: biological control; post-harvest phytopathogen; Penicillium digitatum; Penicillium italicum; Geothrichum citri-aurantii

Key Contribution: This review demonstrates the potential of alternative methods for the control of diseases that occur in the postharvest of citrus.

\section{Introduction}

Citrus is one of the most produced fruit genus. Grown in more than 100 countries, this group is composed by several species, including oranges, tangerines, mandarins, grapefruits, lemons, and limes [1]. The impact of citrus agroindustry in the international economy is huge. Besides their value as commodities, they also provide employment in many segments involved in its production cycle: harvesting, handling, transportation, and storage. In 2017, the global orange production reached 47.6 million metric tons (tons) and is expected to expand 4.2 million in 2018/2019 due to favorable weather in Brazil and United States, two of the most important orange producers in the world [2].

Over 20 different kinds of postharvest diseases have been reported in citrus and they are the main cause of fruit spoilage, resulting in massive economic losses [3]. Moreover, fungal growth in fruit may lead to production of mycotoxins, including potential carcinogenic agents such as citrinin and patulin [4], as well as tremorgenic compounds, for example tryptoquivalines [5], therefore representing a threat to human and animal life. 
Green mold, blue mold, and sour rot, caused by Penicillium digitatum, P. italicum, and Geotrichum citri-aurantii, respectively, are the main citrus postharvest diseases [6]. P. digitatum, alone, is responsible for approximately $90 \%$ of total postharvest losses [7]. The fruits are contaminated through skin postharvest damage during their picking, packaging, storage, and transportation [3].

The interaction between citrus fruit and these phytopathogens is not fully understood, but some factors are known to affect this interaction in order to increase the fungus pathogenicity. P. digitatum and P. italicum are known to secrete organic acids during infection, leading to an optimal $\mathrm{pH}$ for its cell wall-degrading enzymes, such as polygalacturonases (PG) [8,9]. Moreover, P. digitatum also produce catalase during infection, an antioxidant enzyme that decomposes hydrogen peroxide, the main defense mechanism in citrus [10].

In order to deal with these fungi, chemical fungicides have been the main focus of research over the past decades. P. digitatum and P. italicum can be efficiently controlled by imazalil, thiabendazole, or pyrimethanil, but these fungicides are not effective against sour rot. For the control of G. citri-aurantii, guazatine, and propiconazole can be applied, although they are not allowed in some producing countries such as Brazil [11]. However, widespread use of chemical fungicides has caused the proliferation of resistant strains of these phytophatogens, compromising the effectiveness of these treatments [12]. Furthermore, concerns about environmental contamination and risks associated to human health have been raised around the accumulation of their residues in food.

Finding commercially viable, effective, alternative control methods has been a leading challenge for researchers, especially for controlling G. citri-aurantii, since there are fewer options available of acceptable chemical fungicides. Many alternatives have been proposed, including the application of antagonistic microorganisms and natural antimicrobial substances. Natural antimicrobial substances, especially plant extracts, are considered relatively safe, presenting low toxicity and high decomposability due to their natural origin, raising particular interest for use in these natural products [13].

Thus, the application of biocontrol agents has been an alternative for synthetic chemical fungicides. However, more research is necessary to understand their mechanism of action and effectiveness in different infection levels; this knowledge is crucial to implement their use as practical control agents. Therefore, the use of alternative postharvest biological control methods, both non-polluting and possessing low toxicity are reviewed here, highlighting advances presented in the literature in the recent years.

\section{Alternative Control Methods}

\subsection{Microrganisms}

Besides fungicides, other agricultural practices such as irradiation application (light emitting diode, gamma radiation, or UV radiation) [14-17], thermotherapy [18-20], biocontrol agents (BCA) [21-23], and salt solution $[24,25]$ may be used to control postharvest diseases. In the past thirty years, there have been extensive research activities to explore and develop strategies based on microbial antagonists to biologically control postharvest pathogens [26-30]. This section focuses on the natural products and BCA described to be effective to control postharvest diseases.

BCA have been used in post-harvested fruits and its mechanism of action is poorly described in the literature for the majority of microorganisms (either bacteria or yeasts). However, it is supposed that more than one control mechanism could be acting simultaneously over the host-pathogen-antagonist and environment interactions [30]; others include: antibiosis [30,31], competition for nutrients or space [32], induction of resistance in citrus fruits [33,34], secretion of specific enzymes [35], stimulation of ROS in host tissues [36], mycoparasitism, and biofilm formation [37,38].

The use of yeasts as antagonists has been extensively studied, due to their high inhibitory capacity and the ability to colonize surfaces for a long period. The so-called "killer yeasts" yeast strains have the 'killer' phenotype $(\mathrm{K}+)$ and can produce the "killer proteins" that are potential antifungal agents; this feature is a biological advantage against others competing microbial [39-41]. Ferraz et al. reported 
that Rhodotorula minuta, Candida azyma, and Aureobasidium pullulans presented killer activity against the citrus pathogen $G$. citri-aurantii, deforming fungal hyphae and suppressing pathogen development [11]. Saccharomyces cerevisiae is another example of yeast that often presents killer activity [40,42-44].

Besides yeasts, bacteria are also promising BCA: Bacillus [45,46], Lactobacillus [47,48], and Streptomyces sp. [49,50] genus have been studied as BCA against citrus pathogens. Bacteria of Bacillus genus can act as antagonist through antibiotics or volatile organic compound (VOC) production that can induce the increase of plants resistance. Leelasuphakul et al. verified that strains of Bacillus subtilis found in soil were able to delay the spore germination of Penicillium digitatum by the action of water-soluble antibiotic secondary metabolites, proteins, enzymes, and VOC production [45]. As for Lactobacillus, metabolites such as 3-phenyllactic acid and allyl phenylacetate isolated from L. plantarum IMAU10014 had their antifungal activities against Penicillium digitatum observed in vitro by Wang et al. [47]. Finally, Streptomyces sp. had been tested in vitro and in vivo against P. digitatum and other pathogens $[49,50]$. Metabolites from Streptomyces RO3 cultures with molecular masses higher than 2000 Da showed fungicidal action and in vivo tests indicated that the green mold disease incidence decreased when treated with Streptomyces RO3 metabolites [49].

Among the alternatives reported in the literature, the induction of host resistance to pathogen by microorganisms with 'killer' activity has been pointed as a promising option for plant disease control, since they are active against a broad spectrum of pathogens and are safer than other alternatives [41,51]. For example, Parafati et al. related that the yeasts Wickerhamomyces anomalus, Metschnikowia pulcherrima, and $A$. pullulans increased the activities of peroxidase and superoxide dismutase in mandarins, reducing the incidence and severity of blue mold on these fruits [52]. Unfortunately, the activities and mechanisms of interaction of most 'killers' have not yet been well elucidated $[11,41,44]$, being an open research field.

Another gap in the search for BCA against citrus pathogens is that the majority of the studies focuses only in P. digitatum and the other citrus pathogens such as P. italicum and G. citri-aurantii are less studied and also represent a problem for citriculture. As mentioned before, there are few fungicides active against sour rot and other approaches such as BCA could be explored to discover alternative methods to control this phytopathogen. However, few BCA are reported to control this disease. One possibility to solve this problem could be the evaluation of BCA already pointed as active against P. digitatum or other phytopathogens to control G. citri-aurantii.

Table 1 lists some known biocontrol agents and their mode of action against P. digitatum, P. italicum, and G. citri-aurantii. 
Table 1. Biocontrol agents (BCA) used against P. digitatum, P. italicum, and G. citri-aurantii.

\begin{tabular}{|c|c|c|c|c|}
\hline Antagonist & Agent & Mechanism & Target Pathogen & References \\
\hline \multirow{16}{*}{ Yeast } & $\begin{array}{l}\text { Wickerhamomyces anomalus (or } \\
\text { Pichia anomala) }\end{array}$ & $\begin{array}{l}\text { Antibiosis, competition for nutrients, fruit resistance } \\
\text { induction and 'killer' activity }\end{array}$ & P. digitatum P. italicum & {$[39-41,52]$} \\
\hline & Saccharomyces cerevisiae & Competition for nutrients or space and 'killer' activity & P. digitatum P. italicum & {$[40,41,43,44]$} \\
\hline & Candida oleophila & $\begin{array}{l}\text { Resistance induction. Increase phenylalanine ammonia lyase } \\
\text { activity and accumulation of the phytoalexins such as } \\
\text { scoparone, scopoletin, and umbelliferone }\end{array}$ & P. digitatum P. italicum & {$[33,53]$} \\
\hline & $\begin{array}{l}\text { Saccharomycopsis crataegensis }+ \\
\text { sodium bicarbonate }\end{array}$ & Not specified & P. digitatum & [54] \\
\hline & $\begin{array}{l}\text { Kluyveromyces marxianus }+ \\
\text { sodium bicarbonate }\end{array}$ & $\begin{array}{l}\text { Competition for nutrient and space. The salt stimulates } K \text {. } \\
\text { marxianus growth and it inhibits fungal spore germination }\end{array}$ & P. digitatum & [55] \\
\hline & Rhodosporidium paludigenum & $\begin{array}{l}\text { Fruit resistance induction. Increase in ethylene production } \\
\text { and expression of defensive genes }\end{array}$ & P. digitatum & [56] \\
\hline & Pichia membranifaciens & Competition for nutrients or space & P. digitatum & [57] \\
\hline & $\begin{array}{l}\text { Metschnikowia pulcherrima, and } \\
\text { Aureobasidium pullulans }\end{array}$ & $\begin{array}{l}\text { Competition for nutrients and fruit resistance induction by } \\
\text { influencing peroxidase and superoxide dismutase activities }\end{array}$ & P. digitatum P. italicum & [52] \\
\hline & Candida stellimalicola & $\begin{array}{l}\text { 'Killer' activity, production of chitinase, and inhibition of } \\
\text { conidial germination }\end{array}$ & P. italicum & [44] \\
\hline & $\begin{array}{l}\text { Cryptococcus laurentii associated } \\
\text { with cinnamic acid }\end{array}$ & $\begin{array}{l}\text { Different influence of cinnamic acid on the antagonistic yeast } \\
\text { and the pathogen, leading to synergistic effect }\end{array}$ & P. italicum & [58] \\
\hline & Metschnikowia citriensis & Biofilm formation, adhesion to mycelia, and iron depletion & P. digitatum P. italicum & [53] \\
\hline & Pseudozyma antarctica & Direct parasitism & P. digitatum P. italicum & [53] \\
\hline & $\begin{array}{l}\text { Rhodotorula minuta, Candida azyma, } \\
\text { and Aureobasidium pullulans }\end{array}$ & 'Killer' activity and hydrolytic enzyme production & G. citri-aurantii & [11] \\
\hline & Debaryomyces hansenii & Competition for space and nutrients & P. digitatum P. italicum & {$[32,59,60]$} \\
\hline & $\begin{array}{l}\text { Kazachstania exígua and } \\
\text { Pichia fermentans }\end{array}$ & 'Killer' activity & P. digitatum P. italicum & [41] \\
\hline & Bacillus subtilis & $\begin{array}{l}\text { Water soluble antibiotics, proteins, enzymes, and } \\
\text { VOC production }\end{array}$ & P. digitatum & {$[43,45]$} \\
\hline
\end{tabular}


Table 1. Cont

\begin{tabular}{|c|c|c|c|c|}
\hline Antagonist & Agent & Mechanism & Target Pathogen & References \\
\hline \multirow{4}{*}{ Bacteria } & Bacillus amyloliquefaciens & $\begin{array}{l}\text { Great amounts of antibiotics produced in vitro, however, still } \\
\text { not effective for green mold control in vivo }\end{array}$ & P. digitatum & [46] \\
\hline & Lactobacillus plantarum & $\begin{array}{l}\text { Metabolites 3-phenyllactic acid and benzeneacetic acid, } \\
\text { 2-propenyl ester with antifungal activity }\end{array}$ & P. digitatum & {$[47,48]$} \\
\hline & Streptomyces sp. & Metabolites with higher mass than 2000 and fungicidal effect & P. digitatum G. citri-aurantii & {$[49,50]$} \\
\hline & Streptomyces violascens & $\begin{array}{l}\text { Extracellular antifungal compounds that inhibits fungal spore } \\
\text { germination and antibiosis }\end{array}$ & G. citri-aurantii & {$[61]$} \\
\hline
\end{tabular}




\subsection{Natural Products}

Besides BCA, the use of chemicals isolated from natural sources may be an interesting approach to control P. digitatum; these include alkaloids [62], chitosan [26,63-66], carvacrol and thymol [67], citral [68], citronellal [69], and several other compounds isolated from essential oils (EOs) and plant extracts $[22,70,71]$.

Olmedo et al. assessed the antifungal activity of six $\beta$-carboline alkaloids (harmine, harmol, norharmane, harmane, harmaline, and harmalol) against $P$. digitatum and Botrytis cinerea. They observed that harmol is more active than harmaline and harmalol, due to the differences in properties such as aromaticity, acidity, planarity, and polarity [62]. Table 2 shows some plant natural products that have been currently studied as control strategies against P. digitatum, P. italicum, and G. citri-aurantii; lists that are more extensive can be found in [22,71].

The natural products highlighted in Table 2 are summarized in Figure 1. The global Venn diagram (Figure 1) displays natural products activity distribution against P. italicum, P. digitatum, and G. citri-aurantii. The Venn diagram clearly indicates a significant number of natural products active against $P$. digitatum and $P$. italicum; however, few natural products have been studied to control G. citri-aurantii.

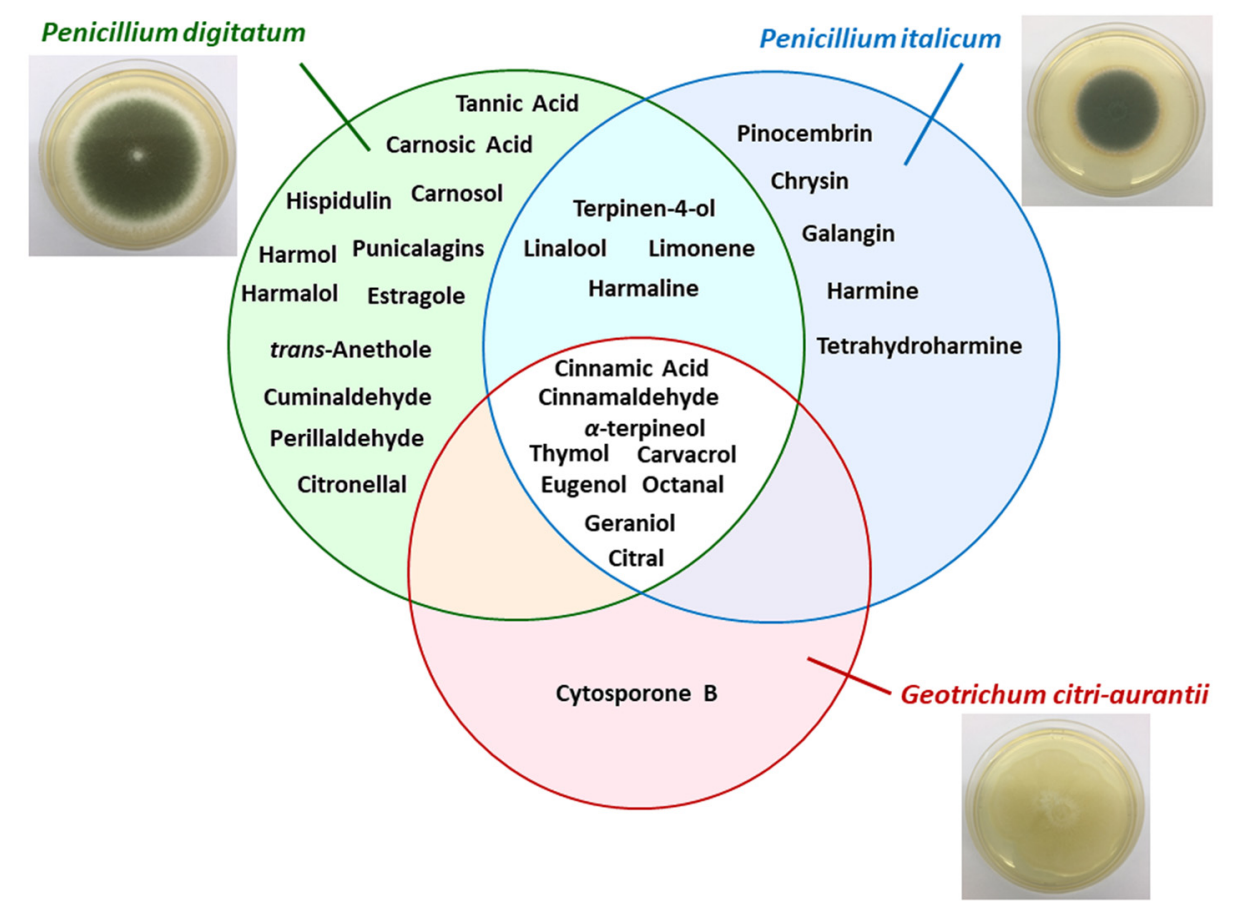

Figure 1. Venn diagram comparing the number of active natural products against the different postharvest citrus pathogens. 
Table 2. Natural products extracted in plants as control strategies against P. digitatum, P. italicum, and G. citri-aurantii.

\begin{tabular}{|c|c|c|c|c|c|}
\hline Plant/Fruit & Pathogen (s) & Extract/Method & Natural Products & Details & References \\
\hline Chinese propolis & P. italicum & $\begin{array}{l}\text { 1) Ethyl acetate (3 times); } \\
\text { 2) chloroform; 3) ethanol } \\
\text { and water; 4) methanol }\end{array}$ & Pinocembrin & $\begin{array}{l}\text { Pinocembrin acts against } P \text {. italicum through } \\
\text { inhibition on respiration and interference of } \\
\text { energy homeostasis }\end{array}$ & [72] \\
\hline Citrus aurantium & $\begin{array}{l}\text { P. digitatum } \\
\text { P. italicum }\end{array}$ & $\begin{array}{l}\text { Hydrodistillation (peels, } \\
\text { leaves, and flowers) }\end{array}$ & $\begin{array}{l}\alpha \text {-terpineol, terpinen-4-ol, } \\
\text { linalool, and limonene }\end{array}$ & $\begin{array}{l}\text { Essential oils (EOs) of flowers and leaves } \\
\text { reduced the growth of pathogen, while EO of } \\
\text { peels was inactive }\end{array}$ & [73] \\
\hline Citrus eticulate Blanco & P. digitatum & - & Citral & $\begin{array}{l}\text { Antifungal activity of citral was tested in vitro } \\
\text { and in vivo and combined with the wax showed } \\
\text { potential for control applications }\end{array}$ & [68] \\
\hline Citrus fruits & $\begin{array}{l}\text { P. italicum } \\
\text { P. digitatum }\end{array}$ & Commercial product & Octanal & Octanal inhibits the fungal mycelial growth & [74] \\
\hline Citrus fruits & P. italicum & Commercial product & Citral & $\begin{array}{l}\text { Citral inhibits the mycelial growth of } P \text {. italicum } \\
\text { causing disruption of cell membrane integrity }\end{array}$ & [75] \\
\hline $\begin{array}{l}\text { Citrus paradise Macf. } \\
\text { (Grapefruit fruit) }\end{array}$ & P. digitatum & - & Chitosan and salicylic acid & $\begin{array}{l}\text { Chitosan combined with salicylic acid had better } \\
\text { treatment of green mold than these isolated } \\
\text { compounds, without compromising the quality } \\
\text { of fruit. }\end{array}$ & [26] \\
\hline Citrus sinensis Osbeck & P. digitatum & Commercial product & Citronellal & $\begin{array}{l}\text { Citronellal was able to inhibit spores } \\
\text { germination and mycelial growth. Just as citral, } \\
\text { the compound combined with wax reduced the } \\
\text { incidence rate }\end{array}$ & [69] \\
\hline Laminaceae spp. & $\begin{array}{l}\text { P. digitatum } \\
\text { P. italicum }\end{array}$ & - & Carvacrol and thymol & $\begin{array}{l}\text { The mechanisms that have been proposed for } \\
\text { these compounds are: 1) morphological } \\
\text { deformation and deterioration of the conidia } \\
\text { and hyphae; 2) hydroxyl group and systems } \\
\text { with delocalized electrons has important role for } \\
\text { antimicrobial effect }\end{array}$ & [69] \\
\hline
\end{tabular}


Table 2. Cont

\begin{tabular}{|c|c|c|c|c|c|}
\hline Plant/Fruit & Pathogen (s) & Extract/Method & Natural Products & Details & References \\
\hline $\begin{array}{l}\text { Peganum harmala } L . \\
\text { (harmal seeds) }\end{array}$ & P. italicum & Ethanol & $\begin{array}{l}\text { Harmine, harmaline, and } \\
\text { tetrahydroharmine (THH) }\end{array}$ & $\begin{array}{l}\text { Harmal extracts showed strong antifungal } \\
\text { activity against } P \text {. italicum and its activity is } \\
\text { related to alkaloids harmine, harmaline e THH }\end{array}$ & [76] \\
\hline Peganum harmala L. & P. digitatum & Commercial product & $\begin{array}{l}\text { Harmol, harmaline, harmalol, } \\
\text { harmane, and norharmane }\end{array}$ & $\begin{array}{l}\text { It was tested the antifungal activity of } \\
\beta \text {-carbolines against } P \text {. digitatum and Botrytis } \\
\text { cinerea. Harmol showed highest antifungal } \\
\text { activity after } 24 \mathrm{~h} \text {. }\end{array}$ & [63] \\
\hline $\begin{array}{l}\text { Pimpinella anisum and } \\
\text { Carum carvi }\end{array}$ & P. digitatum & Hydrodistillation (seeds) & $\begin{array}{l}\text { trans-anethole, estragole } \\
\text { (anise oil), cuminaldehyde, } \\
\text { and perillaldehyde (black } \\
\text { caraway) }\end{array}$ & $\begin{array}{l}\text { EO were able in vitro of reduce the germination, } \\
\text { the mycelial growth of pathogen and the } \\
\text { incidence of disease symptoms }\end{array}$ & [77] \\
\hline $\begin{array}{l}\text { Populus } \times \text { euramericana } \\
\text { cv. 'Neva' (poplar } \\
\text { buds) }\end{array}$ & P. italicum & Dichloromethane & $\begin{array}{l}\text { Flavonoids of pinocembrin, } \\
\text { chrysin, and galangin }\end{array}$ & $\begin{array}{l}\text { Antifungal compounds from poplar buds active } \\
\text { fraction, identified by HPLC-MS, had antifungal } \\
\text { effect in the fungal hyphae analyzed by scanning } \\
\text { electron microscopy and transmission electron } \\
\text { microscopy images }\end{array}$ & [78] \\
\hline Punica Granatum & P. digitatum & Ethanol/water (4:1) & $\begin{array}{l}\text { Phenolic compounds with a } \\
\text { prevalence of punicalagins }\end{array}$ & $\begin{array}{l}\text { Pomegranate peel extract has a broad range of } \\
\text { antifungal activity }\end{array}$ & [13] \\
\hline Ramulus cinnamomi & $\begin{array}{l}\text { P. digitatum } P \text {. } \\
\text { italicum } G . \\
\text { citri-aurantii }\end{array}$ & $\begin{array}{l}\text { Ethyl acetate and } \\
\text { n-buthanol }\end{array}$ & $\begin{array}{l}\text { Cinnamic acid and } \\
\text { cinnamaldehyde }\end{array}$ & $\begin{array}{l}\text { Through }{ }^{1} \mathrm{H} \text {-NMR-based metabolomics it was } \\
\text { identified the extracts related to antifungal } \\
\text { activity of Ramulus cinnamomi after } 4,8 \text {, and } 12 \mathrm{~h} \text {. } \\
\text { The antifungal mechanism of cinnamaldehyde it } \\
\text { was also analyzed by }{ }^{1} \mathrm{H}-\mathrm{NMR}\end{array}$ & [79] \\
\hline Rosmarinus officinalis $L$. & P. digitatum & $\begin{array}{l}\text { Hydrodistillation (for EO) } \\
\text { and methanol }\end{array}$ & $\begin{array}{c}\text { Flavonoids, polyphenols, and } \\
\text { essential oils }\end{array}$ & $\begin{array}{l}\text { EO act in the fungal cells by disrupting the } \\
\text { membrane permeability and the osmotic balance }\end{array}$ & [80] \\
\hline Salvia fruticosa Mill. & P. digitatum & Ethyl acetate & $\begin{array}{c}\text { Carnosic acid, carnosol, and } \\
\text { hispidulin }\end{array}$ & $\begin{array}{l}\text { Compounds that have antifungal properties, } \\
\text { according to its compositions, structures/activity, } \\
\text { and literature }\end{array}$ & [81] \\
\hline
\end{tabular}


Table 2. Cont.

\begin{tabular}{|c|c|c|c|c|c|}
\hline Plant/Fruit & Pathogen (s) & Extract/Method & Natural Products & Details & References \\
\hline Sapium baccatum & P. digitatum & Commercial product & Tannic acid & $\begin{array}{l}\text { In vitro antifungal activity to } P \text {. digitatum was } \\
\text { verified between } 400 \text { and } 1000 \mu \mathrm{g} \mathrm{mL}-1 \text { of tannic } \\
\text { acid inoculated in Ponkan fruit was sufficient to } \\
\text { inhibit the mycelial growth of } 45 \% \text { to } 100 \%\end{array}$ & [82] \\
\hline Solanum nigrum & P. digitatum & Aqueous extract (leaves) & $\begin{array}{l}\text { Alkaloids, flavonoids, } \\
\text { saponins, steroids, glycosides, } \\
\text { terpenoids, and tannins }\end{array}$ & $\begin{array}{l}\text { Bioactive compounds that has pharmacological } \\
\text { prospects for development of drugs }\end{array}$ & [83] \\
\hline $\begin{array}{l}\text { Thymus species }(T . \\
\text { leptobotris, T. riatarum, } \\
\text { T. broussonnetii subsp. } \\
\text { hannonis, and T. } \\
\text { satureioides subsp. } \\
\text { pseudomastichina) }\end{array}$ & $\begin{array}{l}\text { P. digitatum } P . \\
\text { italicum } G . \\
\text { citri-aurantii }\end{array}$ & Hydrodistillation & $\begin{array}{l}\text { Thymol, carvacrol, geraniol, } \\
\text { eugenol, octanal, and citral }\end{array}$ & $\begin{array}{l}\text { EO of four Thymus species showed antifungal } \\
\text { activity. Through GC-MS, MIC, and previous } \\
\text { studies determined the principal active } \\
\text { compounds }\end{array}$ & [84] \\
\hline Thymus leptobotris & $\begin{array}{l}\text { P. digitatum } P . \\
\text { italicum } G . \\
\text { citri-aurantii }\end{array}$ & Methanol, chloroform & Thymol and carvacrol & $\begin{array}{l}\text { The antifungal screening from EO obtained from } \\
21 \text { plants showed that the EO from Thymus } \\
\text { leptobotris had the highest fungistatic effect. The } \\
\text { active compounds were identified in previous } \\
\text { studies. }\end{array}$ & [85] \\
\hline Thymus vulgaris L. & $\begin{array}{l}\text { P. italicum } P . \\
\text { digitatum }\end{array}$ & - & Thymol & $\begin{array}{l}\text { EO of thyme inhibited the mycelium growth } \\
\text { (MIC } 0.13 \mu \mathrm{L} \mathrm{mL}^{-1} \text { ) and spore germination } \\
\text { (MIC } 0.50 \mu \mathrm{LL}^{-1} \text { ) in vitro and in vivo }\end{array}$ & [86] \\
\hline $\begin{array}{l}\text { Withania somnifera }+ \\
\quad \text { Acacia seyal }\end{array}$ & P. digitatum & $\begin{array}{c}\text { Methanol/acetone/water-7:7:1, } \\
v / v(\text { dried plant } \\
\text { powder-1:20 w/v) }\end{array}$ & $\begin{array}{l}\text { Insoluble and soluble } \\
\text { phenolic compounds }\end{array}$ & $\begin{array}{l}\text { Application of plants extract (W. somnifera and } A \text {. } \\
\text { seyal) in the sick host, induced plant resistance } \\
\text { through change of phenolic concentration } \\
\text { (phenylpropanoid pathway) }\end{array}$ & [87] \\
\hline
\end{tabular}


Garlic [88], neem [89], Withania somnifera L. and Acacia seyal L. [87], mustard, and radish [90] also have been reported as effective in controlling P. digitatum. Recently, Zhu et al. reported the antifungal activity of tannic acid on P. digitatum. In vivo tests showed significant decrease of disease signals of $P$. digitatum by inhibiting its mycelial growth and spore germination. Storage tests shown that tannins reduce the severity of green mold on citrus by $70 \%$. The authors suggest that antifungal activity mechanism of tannic acid is related to the disruption of the cell walls and the plasmatic membrane, causing leakage of intracellular contents such as sugars [82].

Extracts from chili peppers and ginger were also proposed to control or inhibit postharvest diseases in citrus [91]. Singh et al. tested different concentrations of the plant extracts of the Zingier officinale $L$. (Ginger) and Capsicum frutescence L. (Chilly) against P. digitatum, Aspergillus niger, and Fusarium sp. isolated from naturally infected citrus. $P$. digitatum, specifically, had a reduction on colony development with inhibition zones of $51.5 \%, 69.2 \%, 74 \%$, and $83.1 \%$ for Zingier officinale L. extract, and $56.4 \%$, $64,1 \%, 76.6 \%$, and $100 \%$ for Capsicum frutescence $L$. at concentration of 500, 1000, 2000, and 3000 ppm, respectively [91].

Besides the above-mentioned natural products used against $P$. digitatum, synergism between compounds have also been tested. Shi et al. studied the effects of chitosan and salicylic acid (SA), both isolated and mixed, on the control of green mold decay in grapefruit. The results showed that combination of chitosan with SA was effective to control green mold than either compound alone (significant efficacy of biocontrol agents against green mold decay induced by SA application in citrus fruits have previously been studied) [26]. Furthermore, significant reduction on lesion diameter and disease incidence was observed. Additionally, it was observed that treatment with chitosan/SA blends increased the content on ascorbic acid and total soluble solids in the fruits, providing a longer shelf life [26].

P. italicum causes the blue mold decay and represents one of the most problematic postharvest citrus infection, compromising fruit integrity during storage and transportation [92]. Currently, the blue mold is primarily controlled by the synthetic fungicide applications, such as thiabendazole and imazalil [44]. Regarding Imazalil-resistant biotypes P. digitatum is more common, whereas resistant P. italicum is rare [93].

Plant extracts studied as an alternative or complementary control agents to currently used fungicides may be attractive because of their potential antifungal activity, non-phytotoxicity and biodegradability [94-97]. Askarne et al. evaluated the antifungal activity of 50 species of plants collected in different regions of southern Morocco. In vitro antifungal activity showed that among them, Anvillea radiata and Thymus leptobotrys completely inhibited mycelial growth of P. italicum at concentrations of $10 \% \mathrm{~m} / \mathrm{v}$ [98]. In addition, Asteriscus graveolens, Bubonium odorum, Ighermia pinifolia, Inula viscosa, Halimium umbellatum, Hammada scoparia, Rubus ulmifolius, Sanguisorba minor, and Ceratonia siliqua were also effective against $P$. italicum with inhibition of mycelial growth greater than $75 \%$. The species on in vitro studies were also tested in vivo against the blue mold in citrus. The incidence of blue mold was significantly reduced to 5 and $25 \%$ when oranges were treated with aqueous extracts of H. umbellatum and I. viscosa (compared to $98 \%$ in the control), indicating the antifungal potential of these materials against $P$. italicum.

Kanan and Al-Najar reported the effective in vitro and in vivo antifungal activity of fenugreek (Trigonella foenum-graecum L.), harmal seeds (Peganum harmala L.), garlic cloves (Allium sativum L.), cinnamon bark (Cinnamomum cassia L.), sticky fleabane leaves (Inula viscose L.), nightshade leaves, and fruits (Solanum nigrum L.) against $P$. italicum isolates. Cinnamon, garlic, and sticky fleabane methanolic fractions resulted in complete inhibition of this pathogen [76].

The high antifungal activity against $P$. italicum of crude extracts cinnamon, as well as the corresponding methanolic, hexanic, and aqueous fractions was related to the high content of cinnamaldehyde, eugenol, cinnamic acid, flavonoids, alkaloids, tannins, anthraquinones, and phenolic compounds, some of them reported before as active antifungal agents. Among them, eugenol and cinnamaldehyde have been consistently reported to be the main antifungal components of 
cinnamon [79,99], representing potential, environmentally benign candidates for postharvest disease control. In addition, harmal extract was pointed also as highly effective extract against $P$. italicum in vitro. The activity of the harmal crude extracts may be related to the content of alkaloids such as harmine, harmaline, and tetrahydroharmine besides phenolic compounds that can alter the permeability of fungal cells [76]. The exact mechanism of action of phenols has not yet been determined; however, it is already known that they can inactivate essential enzymes and disrupt function of the genetic material [100].

Several studies have reported natural antifungal compounds against $P$. italicum produced by different sources. Essential oils, for instance, represent a low-toxic effects alternative and are reported to possess strong inhibitory effects on crop contaminated by P. italicum [74]. Among the major volatile constituents are limonene, $\beta$-linalool, $\alpha$-terpineol, citral, and octanal, the latter reportedly exhibits antifungal activity against some postharvest pathogens such as P. digitatum, P. italicum, and P. ulaiense [101,102]. Regarding the mode of action, Tao et al. attributed its activity against mycelial growth of P. italicum and P. digitatum to the disruption of the cell membrane integrity and leakage of ions and other cell contents [74]. A similar mechanism of activity against postharvest citrus pathogens was attributed to citral, present in citrus EO that is able to alter the morphology of P. italicum hyphae [75].

Chinese propolis has been pointed as active against blue mold and the flavonoid pinocembrin (5,7-dihydroxyflavanone) was identified as one of its main active antifungal constituents. Peng et al. studied the inhibitory effect of this compound on P. italicum with particular attention to its response to the mycelial growth and energy metabolism by interfering in energy homeostasis and cell membrane damage of the pathogen. They observed that mycelial growth and spore germination were nearly completely inhibited with inhibitive percentage up to 93 and $97 \%$, respectively, for pinocembrin concentrations of $400 \mathrm{mg} / \mathrm{L}$ [72].

Figure 2 shows the structures of the above mentioned antifungal compounds found in natural extracts and essential oils.

Sour rot of citrus, caused by Geotrichum citri-aurantii, represents another potentially devastating storage disease [103]. Pathogenicity of Geotrichum citri-aurantii on citrus fruit involves secretion of extracellular endo-polygalacturonases (PG) that aid in the rapid breakdown of infected tissues facilitating the disease [104]. The usual fungicides, with the partial exception of sodium o-phenylphenate (SOPP) and propiconazole [105], cannot actively controlled this disease. Yin et al. revealed the first time that cytosporone B-a compound isolated from the endophytic fungus Cytospora sp. and presenting a wide range of antitumor and antimicrobiotic activities-has a promising effect on the control of citrus decay caused by this pathogen, being comparable to that of fungicide prochloraz. Its mechanism of action is suggested to be related to the alteration of the morphology of pathogen cells, causing distortion of the mycelia and loss of membrane integrity [106].

Talibi et al. demonstrated that methanolic extracts Cistus villosus, C. siliqua, and H. umbellatum successfully reduced the disease incidence in vitro caused by G. citri-aurantii with no phytotoxic effects recorded on citrus; on the other hand, ethyl acetate extracts of $A$. radiata, C. villosus, and C. siliqua proved to be the best inhibitors of mycelial growth [107]. Other studies concerning the antifungal properties of organic extracts of plants include materials from Cistus L. species [108] and from extremophile plants from the Argentine Puna [109]. Incidence of sour rot was described to reduce significantly when fruits were treated with Cistus populifolius and Cistus ladanifer methanol extracts [108].

Zhou et al. also reported citral, octanal, and $\alpha$-terpineol to have strong inhibition on G. citri-aurantii, being the former the most potent among them. They induced a decrease on the total lipid content of the cells, indicating the destruction of cellular membranes, disruption of cell membrane integrity, and leakage of cell components [110].

Liu et al. studied the antifungal activity of thyme (Thymus sp.) EO against postharvest sour rot on citrus fruit. It was shown that G. citri-aurantii cells treated with thyme EO showed morphology alteration (collapsed mycelia and arthroconidia structures); additionally, a marked enlargement of 
hypha wall thickness was observed [111]. Those effects can be assigned specially to the presence of thymol (a volatile terpenoid ubiquous in plants with strong, widespread antifungal activities).

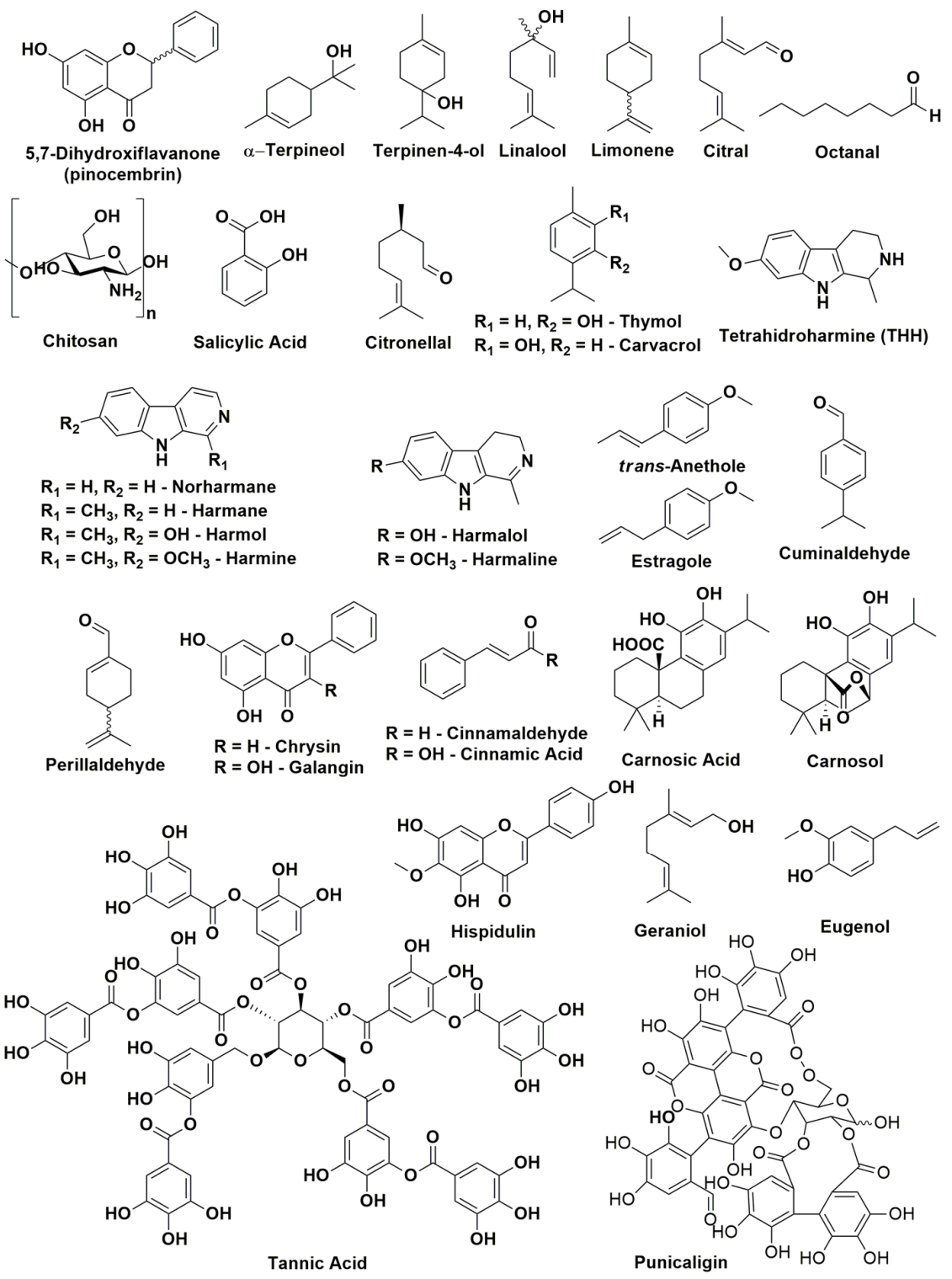

Figure 2. Chemical structures of some antifungal compounds active against $P$. digitatum and P. italicum found in essential oils and natural extracts.

Regnier et al. screened 59 commercially available EO, as well as their major components, to determine their effects on mycelial growth of G. citri-aurantii [6]. Lemong (Cymbopogon citratus) was found to be the most cost-effective option; it was also found that a blend of the lemongrass and spearmint (Mentha spicata) EO could be an alternative for effective multi-target protection against G. citri-aurantii, P. digitatum, and P. italicum [6].

$\mathrm{Xu}$ et al. found that cassia (Cassia sp.) EOs have the ability to control postharvest pathogens and diseases, but their poor solubility in water might prevent its effective use. In order to circumvent this problem, they presented an aqueous microemulsion formulation of cassia EO with ethanol as co-surfactant and Tween 20 as surfactant as antifungal agent against G. citri-aurantii. Both in vitro and in vivo assays showed that cassia EO had stronger activity when encapsulated in the microemulsion [112]. 
The structure of some compounds above listed with activity against $G$. citri-aurantii are shown in Figure 3.<smiles>CCCCCCCCC(=O)c1c(O)cc(O)cc1CC(=O)OCC</smiles>

Cytosporone B

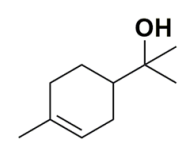

$\alpha$-Terpineol<smiles>CC(C)=CCCC(C)=CC=O</smiles>

Citral<smiles>Cc1ccc(C(C)C)c(O)c1</smiles>

Thymol<smiles>CCCCCCCC=O</smiles>

Octanal<smiles>O=C/C=C/c1ccccc1</smiles>

Cinnamaldehyde

Figure 3. Chemical structures of compound found on plant extracts and essential oils with activity against G. citri-aurantii.

Considering that most plant-derived compounds are usually much less toxic to humans and fauna in general, as well as generally environmentally-friend when compared to fungicides, they should be considered safer and may represent a promising alternative to the existing chemical pesticides in the control of fungal diseases. However, it should be noted that there is a lack of studies concerning non-chemical postharvest treatment against G. citri-aurantii and very little research has been carried out to investigate the use of natural products to control citrus sour rot; therefore, special attention towards this pathogen is needed. Despite the promising antifungal activity of organic extracts of plants, the active antifungal compounds are frequently not identified; the knowledge of the substances accountable for the antifungal activity is fundamental to formulate viable commercial products and develop advanced biofungicides formulations as alternatives to synthetic fungicides to control the citrus postharvest diseases.

\subsection{Commercial Biofungicides}

Biofungicide is the general name given to microorganisms and naturally occurring compounds that possess the ability to control plant diseases [113]. Although the mechanisms of biocontrol in postharvest diseases have not been fully explained in many cases, effective colonization of wounds and competition for nutrients appear to be significant factors for many antagonists. Many microorganisms have shown good potential as basis for commercial biocontrol products due to their efficacy against fungal pathogens in field conditions. Although much research is being conducted in this area, a limited number of biofungicides are available commercially [114-116].

Several commercial biological control formulations based on Trichoderma harzianum, A. pullulans, Bacillus subtilis, Streptomyces griseoviridis, and Gliocladium virens [113,117] have been reported for application against different plant fungal pathogens. Most studies have focused on application of individual biocontrol agents without evaluating their combination with other microorganisms or even with chemical components. Nevertheless, combination BCA that are compatible with each other could offer a new and effective approach improving plant diseases control [114,118].

The major drawback in the commercialization of bioproducts based on BCA is the advancement in the production of shelf-stable formulated products that maintain biocontrol activity similar to that of the fresh cells. Although biofungicides have good action background against host pathogens, there are limitations to their use and effectiveness in the field. Growing demand and interest in bioproducts have led to many marketable brands but the absence of field application reliability of biofungicides has been a significant obstacle in the adoption of these approaches. Despite the remarkable results obtained with biofungicides in the laboratory experiments, some failed to provide consistent disease 
control in field conditions. Thus, these factors are potential contributors to the low dissemination of these products on the market $[113,115,116]$.

Although a reasonable number of studies take into account the exploration of new bioactive compounds that may specifically act against citrus phytopathogens, few products come to commercialization and are widely marketed. In addition to the above problems, the workflow that starts with the discovery of the bioactive compound to the effective elaboration of the final product is still quite complex and is usually a long, iterative process that involves several steps. Figure 4 shows a usual workflow that could be involved in the development of a postharvest biofungicide.

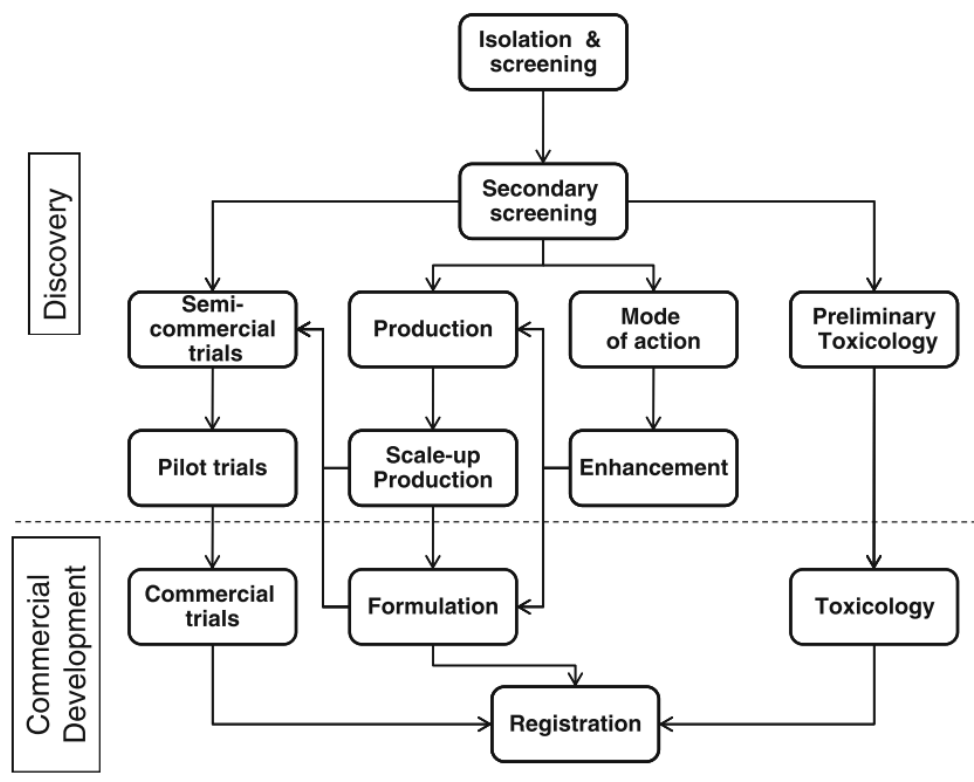

Figure 4. Outline flow of development of a postharvest biocontrol agent. Reprinted from [119]. Copyright 2012, Springer Nature.

According to Nunes, biocontrol agent development is comprised of two main steps: discovery and commercial development. Summarizing the required phases, the first one concerns the isolation and efficacy of the laboratory-based compounds to pilot tests. In this phase must be included evaluation of the action mechanism of the microorganisms, growth media required, improvements in biocontrol activity, and legal procedures involving the patent for the employment of the microorganism as a biopesticide. The commercial development of BCA involves steps including scale-up production, product formulation, biosafety of the microorganism, and registration [119]. The detailed workflow will not be discussed in detail but can be found in previous papers [116,119-121].

Indeed, the complex workflow is a weak point for the development of new products based on biomolecules. Moreover, the high cost of the production and the regulatory barriers to BCA registration in different countries do not encourage their dissemination and recurring issues that need to be overcome [119-122]. To date, four commercially biofungicides, based on microorganisms, were found for the control of postharvest citrus fruit. The yeast Metschnikowia fructicola, for instance, was reported as an efficient biological control agent of postharvest diseases of fruits and vegetables, and it is the bases of the commercial formulated product "Shemer" [122]. Its effect has been reported as a good control of decay in oranges being equivalent to oranges treated with the chemical fungicide, imazalil [123]. Nevertheless, just a few antagonists have achieved the commercial development stage as commercial products. Some of these biofungicides are represented in Table 3. 
Table 3. Commercial biofungicides, based on microorganisms, for the control of postharvest citrus fruit.

\begin{tabular}{cccc}
\hline Microorganism & Product & Targeted Pathogens & References \\
\hline Candida oleophila & Aspire & Botrytis, Penicillium & {$[117]$} \\
Metschnikowia fructicola & Shemer & Botrytis, Penicillium, Rhizopus, Aspergillus & {$[124]$} \\
Pantoea agglomerans & Pantovital & Penicillium, Botrytis, Monilinia & {$[125]$} \\
Pseudomonas syringae & Biosave & Penicillium, Botrytis, Mucor & {$[126]$} \\
\hline
\end{tabular}

Aspire $^{\mathrm{TM}}$, based on Candida oleophila [117], has been commercialized for some years but did not prevail due to low and inconsistent efficacy under commercial conditions, difficulties in market penetration, and perception of the customers and industry [113]. Other products, such as Shemer ${ }^{\mathrm{TM}}$ (based on the yeast M. fructicola), have been more successful [27], and are being used for both preand postharvest application on various fruits and vegetables, including citrus fruit, grapes, peaches, peppers, strawberries, and sweet potatoes.

Despite limited numbers of specific biofungicides, the demand for these products in agriculture as alternatives to synthetic pesticides has increased over the last few years. The adoption and widespread use of biofungicide will make it possible to produce food that are exempt from or have low values of chemical residues. This will contribute to the consumption of more natural, healthy, and safe foods with respect to fungicide usage $[116,127]$. Thus, both regulatory barriers and workflow-related procedures must be improved in order to overcome the challenges in the biofungicide market.

\section{Conclusions}

The information presented in this review reports the potential of alternative methods for the control of postharvest citrus diseases. Despite all the drawbacks regarding the development of new products, a considerable number of studies have been conducted concerning biocontrol strategies of citrus postharvest phytopathogens. Several studies have reported antifungal compounds, mostly against $P$. digitatum, which is responsible for the most important disease found in citrus fruits. Another interesting approach, with good results against green mold, is the application of the biocontrol agent in a mixture with low doses of chemical fungicides during citrus fruit processing. Nevertheless, few studies treat individually the particularities of each fungus and, therefore, many strategies of biocontrol still need to be studied taking into account the different metabolic and enzymatic fungi profile. In this context, there is a lack of studies on postharvest non-chemical treatment against G. citri-aurantii, which causes a decay not controlled by the conventional treatments, and therefore special attention toward this pathogen is necessary. It is very clear that in recent years the interest in biocontrol strategies that minimize the use of chemical pesticides is a worldwide trend, which has driven research in this field. Compounds from biological sources are usually much less toxic to humans as well as environmentally-friendly when compared to synthetic fungicides; for this reason they represent a promising alternative to the existing chemical pesticides in the treatment of fungal diseases. However, as discussed here, several challenges related to the workflow procedures and development of biofungicides still need to be overcome so that new technology can be employed during citrus fruit processing in order to lead to a commercially viable strategy that meets the needs of the producers.

Author Contributions: Writing-original draft preparation: J.M.B., J.R.B., J.H.C., D.Y.A., writing一review and editing: J.M.B., J.G.M.P., and K.C.K, F.A., J.E.C., T.P.F. supervised the conception and design, and final editing of the manuscript.

Funding: This work was supported by grants from Fundação de Amparo à Pesquisa do Estado de São Paulo (grant number FAPESP 2018/03670-0, 2016/20547-2, 2018/13027-8, and 2017/24462-4) and Coordenação de Aperfeiçoamento de Pessoal de Nível Superior, Brasil (CAPES), Finance Code 001.

Acknowledgments: The authors are grateful to the Brazilian institutions Fundação de Amparo à Pesquisa do Estado de São Paulo (grant number FAPESP 2018/03670-0, 2016/20547-2, 2018/13027-8, and 2017/24462-4) and 
Coordenação de Aperfeiçoamento de Pessoal de Nível Superior, Brasil (CAPES), Finance Code 001 for the financial support.

Conflicts of Interest: The authors declare no conflict of interest.

\section{References}

1. Ismail, M.; Zhang, J. Post-harvest citrus diseases and their control. Outlooks Pest Manag. 2004, 15, $29-35$. [CrossRef]

2. USDA/FAS. Citrus: World Markets and Trade. United States Department of Agriculture. Foreing Agricultural Service, February, p. 1-13, 2019. Available online: https://www.fas.usda.gov/data/citrus-world-markets-andtrade (accessed on 30 May 2019).

3. Chen, J.; Shen, Y.; Chen, C.; Wan, C. Inhibition of key citrus postharvest fungal strains by plant extracts in vitro and in vivo: A review. Plants 2019, 8, 26. [CrossRef]

4. Dukare, A.S.; Paul, S.; Nambi, V.E.; Gupta, R.K.; Singh, R.; Sharma, K.; Vishwakarma, R.K. Exploitation of microbial antagonists for the control of postharvest diseases of fruits: A review. Crit. Rev. Food Sci. Nutr. 2019, 59, 1498-1513. [CrossRef] [PubMed]

5. Ariza, M.R.; Larsen, T.O.; Duus, J.Ø.; Barrero, A.F. Penicillium digitatum metabolites on synthetic media and citrus fruits. J. Agric. Food Chem. 2002, 50, 6361-6365. [CrossRef] [PubMed]

6. Regnier, T.; Combrinck, S.; Veldman, W.; Du Plooy, W. Application of essential oils as multi-target fungicides for the control of Geotrichum citri-aurantii and other postharvest pathogens of citrus. Ind. Crops Prod. 2014, 61, 151-159. [CrossRef]

7. Zhu, C.; Sheng, D.; Wu, X.; Wang, M.; Hu, X.; Li, H.; Yu, D. Identification of secondary metabolite biosynthetic gene clusters associated with the infection of citrus fruit by Penicillium digitatum. Postharvest Biol. Technol. 2017, 134, 17-21. [CrossRef]

8. Barmore, C.R.; Brown, G.E. Polygalacturonase from citrus fruit infected with Penicillium italicum. Phytopathol. 1981, 71, 328-331. [CrossRef]

9. Prusky, D.; McEvoy, J.L.; Saftner, R.; Conway, W.S.; Jones, R. Relationship between host acidification and virulence of Penicillium spp. on apple and citrus fruit. Phytopathology 2004, 94, 44-51. [CrossRef] [PubMed]

10. Macarisin, D.; Cohen, L.; Eick, A.; Rafael, G.; Belausov, E.; Wisniewski, M.; Droby, S. Penicillium digitatum suppresses production of hydrogen peroxide in host tissue during infection of citrus fruit. Phytopathology 2007, 97, 1491-1500. [CrossRef] [PubMed]

11. Ferraz, L.P.; Cunha, T.; Silva, A.C.; Kupper, K.C. Biocontrol ability and putative mode of action of yeasts against Geotrichum citri-aurantii in citrus fruit. Microbiol. Res. 2016, 188, 72-79. [CrossRef]

12. Palou, L.; Smilanick, J.L.; Droby, S. Alternatives to conventional fungicides for the control of citrus postharvest green and blue moulds. Stewart Postharvest Rev. 2008, 4, 1-16. [CrossRef]

13. Li Destri Nicosia, M.G.; Pangallo, S.; Raphael, G.; Romeo, F.V.; Strano, M.C.; Rapisarda, P.; Droby, S.; Schena, L. Control of postharvest fungal rots on citrus fruit and sweet cherries using a pomegranate peel extract. Postharvest Biol. Technol. 2016, 114, 54-61. [CrossRef]

14. Ballester, A.R.; Lafuente, M.T. LED Blue light-induced changes in phenolics and ethylene in citrus fruit: Implication in elicited resistance against Penicillium digitatum infection. Food Chem. 2017, 218, 575-583. [CrossRef] [PubMed]

15. Kim, J.J.; Ben-Yehoshua, S.; Shapiro, B.; Henis, Y.; Carmeli, S. Accumulation of scoparone in heat-treated lemon fruit inoculated with Penicillium digitatum Sacc. Plant Physiol. 1991, 97, 880-885. [CrossRef] [PubMed]

16. Jeong, R.D.; Chu, E.H.; Lee, G.W.; Cho, C.; Park, H.J. Inhibitory effect of gamma irradiation and its application for control of postharvest green mold decay of Satsuma mandarins. Int. J. Food Microbiol. 2016, 234, 1-8. [CrossRef] [PubMed]

17. Olmedo, G.M.; Cerioni, L.; González, M.M.; Cabrerizo, F.M.; Volentini, S.I.; Rapisarda, V.A. UVA photoactivation of harmol enhances its antifungal activity against the phytopathogens Penicillium digitatum and Botrytis cinerea. Front. Microbiol. 2017, 8, 347. [CrossRef] [PubMed]

18. Nunes, C.; Usall, J.; Manso, T.; Torres, R.; Olmo, M.; García, J.M. Effect of high temperature treatments on growth of Penicillium spp. and their development on 'Valencia' oranges. Food Sci. Technol. Int. 2007, 13, 63-68. [CrossRef] 
19. Fatemi, S.; Borji, H. The effect of physical treatments on control of Penicillium digitatum decay orange cv. Valencia during storage period. Afr. J. Agric. Res. 2011, 6, 5757-5760. [CrossRef]

20. Mulas, M. Combined effects of fungicides and thermotherapy on post-harvest quality of horticultural commodities. In Fungicides_Beneficial and Harmful Aspects; Thajuddin, N., Ed.; IntechOpen: London, UK, 2011; pp. 133-166.

21. Abraham, A.O.; Laing, M.D.; Bower, J.P. Isolation and in vivo screening of yeast and Bacillus antagonists for the control of Penicillium digitatum of citrus fruit. Biol. Control 2010, 53, 32-38. [CrossRef]

22. Talibi, I.; Boubaker, H.; Boudyach, E.H.; Aoumar, A.A.B. Alternative methods for the control of postharvest citrus diseases. J. Appl. Microbiol. 2014, 117, 1-17. [CrossRef]

23. Mohammadi, P.; Tozlu, E.; Kotan, R.; Şenol Kotan, M. Potential of some bacteria for biological control of postharvest citrus green mould caused by Penicillium digitatum. Plant Protect. Sci. 2017, 53, 134-143. [CrossRef]

24. Youssef, K.; Sanzani, S.M.; Ligorio, A.; Ippolito, A.; Terry, L.A. Sodium carbonate and bicarbonate treatments induce resistance to postharvest green mould on citrus fruit. Postharvest Biol. Technol. 2014, 87, 61-69. [CrossRef]

25. Fallanaj, F.; Ippolito, A.; Ligorio, A.; Garganese, F.; Zavanella, C.; Sanzani, S.M. Electrolyzed sodium bicarbonate inhibits Penicillium digitatum and induces defence responses against green mould in citrus fruit. Postharvest Biol. Technol. 2016, 115, 18-29. [CrossRef]

26. Shi, S.; Wang, F.; Lu, Y.; Deng, J. Combination of chitosan and salicylic acid to control postharvest green mold caused by Penicillium digitatum in grapefruit fruit. Sci. Hortic. 2018, 233, 54-60. [CrossRef]

27. Droby, S.; Wisniewski, M.; Macarisin, D.; Wilson, C. Twenty years of postharvest biocontrol research: Is it time for a new paradigm? Postharvest Biol. Technol. 2009, 52, 137-145. [CrossRef]

28. Sharma, R.R.; Singh, D.; Singh, R. Biological control of postharvest diseases of fruits and vegetables by microbial antagonists: A review. Biol. Control. 2009, 50, 205-221. [CrossRef]

29. Spadaro, D.; Gullino, M.L. State of the art and future prospects of the biological control of postharvest fruit diseases. Int. J. Food Microbiol. 2004, 91, 185-194. [CrossRef]

30. Nunes, C.A.; Manso, T.; Lima-Costa, M.E. Postharvest biological control of citrus fruits. Tree For. Sci. Biotechnol. 2009, 2, 116-126.

31. Waewthongrak, W.; Pisuchpen, S.; Leelasuphakul, W. Effect of Bacillus subtilis and chitosan applications on green mold (Penicilium digitatum Sacc.) decay in citrus fruit. Postharvest Biol. Technol. 2015, 99, 44-49. [CrossRef]

32. Droby, S.; Chalutz, E.; Wilson, C.L.; Wisniewski, M. Characterization of the biocontrol activity of Debaryomyces hansenii in the control of Penicillium digitatum on grapefruit. Can. J. Microbiol. 1989, 35, 794-800. [CrossRef]

33. Droby, S.; Vinokur, V.; Weiss, B.; Cohen, L.; Daus, A.; Goldschmidt, E.E.; Porat, R. Induction of resistance to Penicillium digitatum in grapefruit by the yeast biocontrol agent Candida oleophila. Phytopathology 2002, 92, 393-399. [CrossRef] [PubMed]

34. Lu, L.; Lu, H.; Wu, C.; Fang, W.; Yu, C.; Ye, C.; Shi, Y.; Yu, T.; Zheng, X. Rhodosporidium paludigenum induces resistance and defense-related responses against Penicillium digitatum in citrus fruit. Postharvest Biol. Technol. 2013, 85, 196-202. [CrossRef]

35. Bar-Shimon, M.; Yehuda, H.; Cohen, L.; Weiss, B.; Kobeshnikov, A.; Daus, A. Characterization of extracellular lytic enzymes produced by the yeast biocontrol agent Candida oleophila. Curr. Genet. 2004, 45, 140-148. [CrossRef] [PubMed]

36. Macarisin, D.; Droby, S.; Bauchan, G.; Wisniewski, M. Superoxide anion and hydrogen peroxide in the yeast antagonist-fruit interaction: A new role for reactive oxygen species in postharvest biocontrol? Postharvest Biol. Technol. 2010, 58, 194-202. [CrossRef]

37. Castoria, R.; Caputo, L.; De Curtis, F.; De Cicco, V. Resistance of postharvest biocontrol yeasts to oxidative stress: A possible new mechanism of action. Phytopathology 2003, 93, 564-572. [CrossRef]

38. Benhamou, N. Potential of the mycoparasite, Verticillium lecanii, to protect citrus fruit against Penicillium digitatum, the causal agent of green mold: A comparison with the effect of chitosan. Phytopathology 2004, 94, 693-705. [CrossRef] 
39. Aloui, H.; Licciardello, F.; Khwaldia, K.; Hamdi, M.; Restuccia, C. Physical properties and antifungal activity of bioactive films containing Wickerhamomyces anomalus killer yeast and their application for preservation of oranges and control of postharvest green mold caused by Penicillium digitatum. Int. J. Food Microbiol. 2015, 200, 22-30. [CrossRef]

40. Platania, C.; Restuccia, C.; Muccilli, S.; Cirvilleri, G. Efficacy of killer yeasts in the biological control of Penicillium digitatum on Tarocco orange fruits (Citrus sinensis). Food Microbiol. 2012, 30, 219-225. [CrossRef]

41. Comitini, F.; Mannazzu, I.; Ciani, M. Tetrapisispora phaffii killer toxin is a highly specific $\beta$-glucanase that disrupts the integrity of the yeast cell wall. Microb. Cell Fact. 2009, 8, 55. [CrossRef]

42. Perez, M.F.; Contreras, L.; Garnica, N.M.; Fernández-Zenoff, M.V.; Farías, M.E.; Sepulveda, M.; Ramallo, J.; $\mathrm{Dib}$, J.R. Native killer yeasts as biocontrol agents of postharvest fungal diseases in lemons. PLoS ONE 2016, 11, e0165590. [CrossRef]

43. Kupper, K.C.; Cervantes, A.L.L.; Klein, M.N.; Silva, A.C. Avaliação de microrganismos antagônicos, Saccharomyces cerevisiae e Bacillus subtilis para o controle de Penicillium digitatum. Rev. Bras. Frutic. 2013, 35, 425-436. [CrossRef]

44. Cunha, T.; Ferraz, L.P.; Wehr, P.P.; Kupper, K.C. Antifungal activity and action mechanisms of yeasts isolates from citrus against Penicillium italicum. Int. J. Food Microbiol. 2018, 276, 20-27. [CrossRef] [PubMed]

45. Leelasuphakul, W.; Hemmanee, P.; Chuenchitt, S. Growth inhibitory properties of Bacillus subtilis strains and their metabolites against the green mold pathogen (Penicillium digitatum Sacc.) of citrus fruit. Postharvest Biol. Technol. 2008, 48, 113-121. [CrossRef]

46. Calvo, H.; Marco, P.; Blanco, D.; Oria, R.; Venturini, M.E. Potential of a new strain of Bacillus amyloliquefaciens BUZ-14 as a biocontrol agent of postharvest fruit diseases. Food Microbiol. 2017, 63, 101-110. [CrossRef] [PubMed]

47. Wang, H.K.; Yan, Y.H.; Wang, J.M.; Zhang, H.P.; Qi, W. Production and characterization of antifungal compounds produced by Lactobacillus plantarum IMAU10014. PLoS ONE 2012, 7, e29452. [CrossRef] [PubMed]

48. Matei, A.; Cornea, C.P.; Matei, S.; Matei, G.M.; Rodino, S. Comparative antifungal effect of lactic acid bacteria strains on Penicillium digitatum. Bull. UASVM Food Sci. Technol. 2015, 72, 226-230. [CrossRef]

49. Maldonado, M.C.; Orosco, C.E.; Gordillo, M.A.; Navarro, A.R. In vivo and in vitro antagonism of Streptomyces sp. RO3 against Penicillium digitatum and Geotrichum candidum. Afr. J. Microbiol. Res. 2010, 4, 2451-2456.

50. Najmeh, S.; Hosein, S.B.G.; Sareh, S.; Bonjar, L.S. Biological control of citrus green mould, Penicillium digitatum, by antifungal activities of Streptomyces isolates from agricultural soils. Afr. J. Microbiol. Res. 2014, 8, 1501-1509. [CrossRef]

51. Walling, L.L. Induced resistance: From the basic to the applied. Trends Plant Sci. 2001, 6, 445-447. [CrossRef]

52. Parafati, L.; Vitale, A.; Restuccia, C.; Cirvilleri, G. The effect of locust bean gum (LBG)-based edible coatings carrying biocontrol yeasts against Penicillium digitatum and Penicillium italicum causal agents of postharvest decay of mandarin fruit. Food Microbiol. 2016, 58, 87-94. [CrossRef] [PubMed]

53. Liu, Y.; Yao, S.; Deng, L.; Ming, J.; Zeng, K. Different mechanisms of action of isolated epiphytic yeasts against Penicillium digitatum and Penicillium italicum on citrus fruit. Postharvest Biol. Technol. 2019, 152, 100-110. [CrossRef]

54. Pimenta, R.S.; Silva, J.F.M.; Coelho, C.M.; Morais, P.B.; Rosa, C.A.; Corrêa, A., Jr. Integrated control of Penicillium digitatum by the predacious yeast Saccharomycopsis crataegensis and sodium bicarbonate on oranges. Braz. J. Microbiol. 2010, 41, 404-410. [CrossRef] [PubMed]

55. Geng, P.; Chen, S.; Hu, M.; Haq, M.R.; Lai, K.; Qu, F.; Zhang, Y. Combination of Kluyveromyces marxianus and sodium bicarbonate for controlling green mold of citrus fruit. Int. J. Food Microbiol. 2011, 151, 190-194. [CrossRef] [PubMed]

56. Lu, L.; Xu, S.; Zeng, L.; Zheng, X.; Yu, T. Rhodosporidium paludigenum induced resistance in Ponkan mandarin against Penicillium digitatum requires ethylene-dependent signaling pathway. Postharvest Biol. Technol. 2014, 97, 93-101. [CrossRef]

57. Spadaro, D.; Droby, S. Unraveling the mechanisms used by antagonistic yeast to control postharvest pathogens on fruit. Acta Hortic. 2016, 1144, 63-70. [CrossRef]

58. Li, J.; Li, H.; Ji, S.; Chen, T.; Tian, S.; Qin, G. Enhancement of biocontrol efficacy of Cryptococcus laurentii by cinnamic acid against Penicillium italicum in citrus fruit. Postharvest Biol. Technol. 2019, 149, 42-49. [CrossRef] 
59. Chalutz, E. Postharvest biocontrol of green and blue mold and sour rot of citrus fruit by Debaryomyces hansenii. Plant Dis. 1990, 74, 134-137. [CrossRef]

60. Hernández-Montiel, L.G.; Ochoa, J.L.; Troyo-Diéguez, E.; Larralde-Corona, C.P. Biocontrol of postharvest blue mold (Penicillium italicum Wehmer) on Mexican lime by marine and citrus Debaryomyces hansenii isolates. Postharvest Biol. Technol. 2010, 56, 181-187. [CrossRef]

61. Choudhary, B.; Nagpure, A.; Gupta, R.K. Biological control of toxigenic citrus and papaya-rotting fungi by Streptomyces violascens MT7 and its extracellular metabolites. J. Basic Microbiol. 2015, 55, 1343-1356. [CrossRef]

62. Olmedo, G.M.; Cerioni, L.; González, M.M.; Cabrerizo, F.M.; Rapisarda, V.A.; Volentini, S.I. Antifungal activity of $\beta$-carbolines on Penicillium digitatum and Botrytis cinerea. Food Microbiol. 2017, 62, 9-14. [CrossRef]

63. Lu, L.; Yang, Y.L.J.; Azat, R.; Yu, T.; Zheng, X. Quaternary chitosan oligomers enhance resistance and biocontrol efficacy of Rhodosporidium paludigenum to green mold in satsuma orange. Carbohydr. Polym. 2014, 113, 174-181. [CrossRef] [PubMed]

64. Shao, X.; Cao, B.; Xu, F.; Xie, S.; Yu, D.; Wang, H. Effect of postharvest application of chitosan combined with clove oil against citrus green mold. Postharvest Biol. Technol. 2015, 99, 37-43. [CrossRef]

65. Tayel, A.A.; Moussa, S.H.; Salem, M.F.; Mazrou, K.E.; El-Tras, W.F. Control of citrus molds using bioactive coatings incorporated with fungal chitosan/plant extracts composite. J. Sci. Food Agric. 2016, 96, 1306-1312. [CrossRef] [PubMed]

66. El Guilli, M.; Hamza, A.; Clément, C.; Ibriz, M.; Barka, E.A. Effectiveness of postharvest treatment with chitosan to control citrus green mold. Agriculture 2016, 6, 12. [CrossRef]

67. Pérez-Alfonso, C.O.; Martínez-Romero, D.; Zapata, P.J.; Serrano, M.; Valero, D.; Castillo, S. The effects of essential oils carvacrol and thymol on growth of Penicillium digitatum and P. italicum involved in lemon decay. Int. J. Food Microbiol. 2012, 158, 101-106. [CrossRef] [PubMed]

68. Fan, F.; Tao, N.; Jia, L.; He, X. Use of citral incorporated in postharvest wax of citrus fruit as a botanical fungicide against Penicillium digitatum. Postharvest Biol. Technol. 2014, 90, 52-55. [CrossRef]

69. Wu, Y.; OuYang, Q.; Tao, N. Plasma membrane damage contributes to antifungal activity of citronellal against Penicillium digitatum. J. Food Sci. Technol. 2016, 53, 3853-3858. [CrossRef]

70. Sivakumar, D.; Bautista-Baños, S. A review on the use of essential oils for postharvest decay control and maintenance of fruit quality during storage. Crop Prot. 2014, 64, 27-37. [CrossRef]

71. Solgi, M.; Ghorbanpour, M. Application of essential oils and their biological effects on extending the shelf-life and quality of horticultural crops. Trakia J. Sci. 2014, 12, 198-210.

72. Peng, L.; Yang, S.; Cheng, Y.J.; Chen, F.; Pan, S.; Fan, G. Antifungal activity and action mode of pinocembrin from propolis against Penicillium italicum. Food Sci. Biotechnol. 2012, 21, 1533-1539. [CrossRef]

73. Trabelsi, D.; Hamdane, A.M.; Said, M.B.; Abdrrabba, M. Chemical composition and antifungal activity of essential oils from flowers, leaves and peels of Tunisian Citrus aurantium against Penicillium digitatum and Penicillium italicum. J. Essent. Oil Bear Plants 2016, 19, 1660-1674. [CrossRef]

74. Tao, N.; Jia, L.; Zhou, H.; He, X. Effect of octanal on the mycelial growth of Penicillium italicum and P. digitatum. World J. Microbiol. Biotechnol. 2014, 30, 1169-1175. [CrossRef] [PubMed]

75. Tao, N.; OuYang, Q.; Jia, L. Citral inhibits mycelial growth of Penicillium italicum by a membrane damage mechanism. Food Control 2014, 41, 116-121. [CrossRef]

76. Kanan, G.J.M.; Al-Najar, R.A.-W.K. In vitro and in vivo activity of selected plant crude extracts and fractions against Penicillium italicum. J. Plant Prot. Res. 2009, 49, 341-352. [CrossRef]

77. Aminifard, M.H.; Bayat, H. Antifungal activity of black caraway and anise essential oils against Penicillium digitatum on blood orange fruits. Int. J. Fruit Sci. 2018, 18, 307-319. [CrossRef]

78. Yang, S.; Liu, L.; Li, D.; Xia, H.; Su, X.; Peng, L.; Pan, S. Use of active extracts of poplar buds against Penicillium italicum and possible modes of action. Food Chem. 2016, 196, 610-618. [CrossRef] [PubMed]

79. Wan, C.; Li, P.; Chen, C.; Peng, X.; Li, M.; Chen, M.; Wang, J.; Chen, J. Antifungal activity of Ramulus cinnamomi explored by ${ }^{1} \mathrm{H}-\mathrm{NMR}$ based metabolomics approach. Molecules 2017, 22, 2237. [CrossRef]

80. Hendel, N.; Larous, L.; Belbey, L. Antioxidant activity of rosemary (Rosmarinus officinalis L.) and its in vitro inhibitory effect on Penicillium digitatum. Int. Food Res. J. 2016, 23, 1725-1732.

81. Exarchou, V.; Kanetis, L.; Charalambous, Z.; Apers, S.; Pieters, L.; Gekas, V.; Goulas, V. HPLC-SPE-NMR Characterization of major metabolites in Salvia fruticosa Mill. extract with antifungal potential: Relevance of carnosic acid, carnosol, and hispidulin. J. Agric. Food Chem. 2015, 63, 457-463. [CrossRef] 
82. Zhu, C.; Lei, M.; Andargie, M.; Zeng, J.; Li, J. Antifungal activity and mechanism of action of tannic acid against Penicillium digitatum. Physiol. Mol. Plant Pathol. 2019, 107, 46-50. [CrossRef]

83. Musto, M.; Potenza, G.; Cellini, F. Inhibition of Penicillium digitatum by a crude extract from Solanum nigrum leaves. Biotechnol. Agron. Soc. Environ. 2014, 18, 174-180.

84. Boubaker, H.; Karim, H.; El Hamdaoui, A.; Msanda, F.; Leach, D.; Bombarda, I.; Vanloot, P.; Abbad, A.; Boudyach, E.H.; Aoumar, A.A.B. Chemical characterization and antifungal activities of four Thymus species essential oils against postharvest fungal pathogens of citrus. Ind. Crops Prod. 2016, 86, 95-101. [CrossRef]

85. Ameziane, N.; Boubaker, H.; Boudyach, H.; Msanda, F.; Jilal, A.; Benaoumar, A.A. Antifungal activity of Moroccan plants against citrus fruit pathogens. Agron. Sustain. Dev. 2007, 27, 273-277. [CrossRef]

86. Vitoratos, A.; Bilalis, D.; Karkanis, A.; Efthimiadou, A. Antifungal activity of plant essential oils against Botrytis cinerea, Penicillium italicum and Penicillium digitatum. Not. Bot. Horti Agrobot. 2013, 41, 86-92. [CrossRef]

87. Mekbib, S.B.; Regnier, T.J.C.; Korsten, L. Control of Penicillium digitatum growth on citrus fruit using two plant extracts and their mode of action. Phytoparasitica 2007, 35, 264-276. [CrossRef]

88. Obagwu, J.; Korsten, L. Control of citrus green and blue molds with garlic extracts. Eur. J. Plant Pathol. 2003, 109, 221-225. [CrossRef]

89. Mossini, S.A.G.; Arrotéia, C.C.; Kemmelmeier, C. Effect of neem leaf extract and neem oil on Penicillium growth, sporulation, morphology and Ochratoxin A production. Toxins 2009, 1, 3-13. [CrossRef]

90. Baviskar, R.N. Anti-fungal activity of Launea pinnatifida and Argimone maxicana against post-harvest fungal pathogens in Apple fruits. Int. J. of Life Sciences 2014, 2, 346-349.

91. Singh, H.; Al-samarai, G.; Syarhabil, M. Exploitation of natural products as an alternative strategy to control postharvest fungal rotting of citrus. IJSR 2012, 2, 1-4. [CrossRef]

92. Palou, L. Penicillium digitatum, Penicillium italicum (Green Mold, Blue Mold). In Postharvest Decay; Academic Press: Cambridge, MA, USA, 2014; pp. 45-102.

93. Holmes, G.J.; Eckert, J.W. Sensitivity of Penicillium digitatum and P. italicum to postharvest citrus fungicides in California. Phytopathol. 1999, 89, 716-721. [CrossRef]

94. Du Plooy, W.; Regnier, T.; Combrinck, S. Essential oil amended coatings as alternatives to synthetic fungicides in citrus postharvest management. Postharvest Biol. Technol. 2009, 53, 117-122. [CrossRef]

95. Tripathi, P.; Dubey, N.K.; Shukla, A.K. Use of some essential oils as post-harvest botanical fungicides in the management of grey mould of grapes caused by Botrytis cinerea. World J. Microbiol. Biotechnol. 2008, 24, 39-46. [CrossRef]

96. Fawcett, C.H.; Spencer, D.M. Plant chemotherapy with natural products. Annu. Rev. Phytopathol. 1970, 8, 403-418. [CrossRef]

97. Tripathi, P.; Dubey, N.K. Exploitation of natural products as an alternative strategy to control postharvest fungal rotting of fruit and vegetables. Postharvest Biol. Technol. 2004, 32, 235-245. [CrossRef]

98. Askarne, L.; Talibi, I.; Boubaker, H.; Boudyach, E.H.; Msanda, F.; Saadi, B.; Serghini, M.A.; Aoumar, A.A.B. In vitro and in vivo antifungal activity of several Moroccan plants against Penicillium italicum, the causal agent of citrus blue mold. Crop Prot. 2012, 40, 53-58. [CrossRef]

99. Jham, G.N.; Dhingra, O.D.; Jardim, C.M.; Valente, V.M.M. Identification of the major fungitoxic component of cinnamon bark oil. Fitopatol. Bras. 2005, 30, 404-408. [CrossRef]

100. Telezhenetskaya, M.V.; D'yakonov, A.L. Alkaloids of Peganum harmala. Unusual reaction of peganine and vasicinone. Chem. Nat. Compd. 1991, 27, 471-474. [CrossRef]

101. Scora, K.M.; Scora, R.W. Effect of volatiles on mycelium growth of Penicillium digitatum, P. italicum, and P. ulaiense. J. Basic Microbiol. 1998, 38, 405-413. [CrossRef]

102. Droby, S.; Eick, A.; Macarisin, D.; Cohen, L.; Rafael, G.; Stange, R.; McColum, G.; Dudai, N.; Nasser, A.; Wisniewski, M.; et al. Role of citrus volatiles in host recognition, germination and growth of Penicillium digitatum and Penicillium italicum. Postharvest Biol. Technol. 2008, 49, 386-396. [CrossRef]

103. Mercier, J.; Smilanick, J.L. Control of green mold and sour rot of stored lemon by biofumigation with Muscodor albus. Biol. Control 2005, 32, 401-407. [CrossRef]

104. Nakamura, M.; Suprapta, D.N.; Iwai, H.; Arai, A.K. Comparison of endo-polygalacturonase activities of citrus and non-citrus races of Geotrichum candidum, and cloning and expression of the corresponding genes. Mol. Plant Pathol. 2001, 2, 265-274. [CrossRef] [PubMed] 
105. McKay, A.H.; Förster, H.; Adaskaveg, J.E. Efficacy and application strategies for propiconazole as a new postharvest fungicide for managing sour rot and green mold of citrus fruit. Plant Dis. 2012, 96, 235-242. [CrossRef] [PubMed]

106. Yin, C.; Liu, H.; Shan, Y.; Gupta, V.K.; Jiang, Y.; Zhang, W.; Tan, H.; Gong, L. Cytosporone B as a biological preservative: Purification, fungicidal activity and mechanism of action against Geotrichum citri-aurantii. Biomolecules 2019, 9, 125. [CrossRef] [PubMed]

107. Talibi, I.; Askarne, L.; Boubaker, H.; Boudyach, E.H.; Msanda, F.; Saadi, B.; Aoumar, A.A.B. Antifungal activity of Moroccan medicinal plants against citrus sour rot agent Geotrichum candidum. Lett. Appl. Microbiol. 2012, 55, 155-161. [CrossRef] [PubMed]

108. Karim, H.; Boubaker, H.; Askarne, L.; Talibi, I.; Msanda, F.; Boudyach, E.H.; Saadi, B.; Aoumar, A.A.B. Antifungal properties of organic extracts of eight Cistus L. species against postharvest citrus sour rot. Lett. Appl. Microbiol. 2015, 62, 16-22. [CrossRef] [PubMed]

109. Sayago, J.E.; Ordoñez, R.M.; Kovacevich, L.N.; Torres, S.; Isla, M.I. Antifungal activity of extracts of extremophile plants from the Argentine Puna to control citrus postharvest pathogens and green mold. Postharvest Biol. Technol. 2012, 67, 19-24. [CrossRef]

110. Zhou, H.; Tao, N.; Jia, L. Antifungal activity of citral, octanal and $\alpha$-terpineol against Geotrichum citri-aurantii. Food Control 2014, 37, 277-283. [CrossRef]

111. Liu, X.; Wang, L.P.; Li, Y.C.; Yu, T.; Zheng, X.D. Antifungal activity of thyme oil against Geotrichum citri-aurantii in vitro and in vivo. J. Appl. Microbiol. 2009, 107, 1450-1456. [CrossRef]

112. Xu, S.-X.; Li, Y.-C.; Liu, X.; Mao, L.-J.; Zhang, H.; Zheng, X.-D. In vitro and in vivo antifungal activity of a water-dilutable cassia oil microemulsion against Geotrichum citri-aurantii. J. Sci. Food Agric. 2012, 92, 2668-2671. [CrossRef]

113. Spadaro, D.; Droby, S. Development of biocontrol products for postharvest diseases of fruit: The importance of elucidating the mechanisms of action of yeast antagonists. Trends Food Sci. Technol. 2016, 47, $39-49$. [CrossRef]

114. Alamri, S.A. The synergistic effect of two formulated biofungicides in the biocontrol of root and bottom rot of lettuce. Biocontrol Sci. 2014, 19, 189-197. [CrossRef] [PubMed]

115. Janisiewicz, W.J.; Jeffers, S.N. Efficacy of commercial formulation of two biofungicides for control of blue mold and gray mold of apples in cold storage. Crop Prot. 1997, 16, 629-633. [CrossRef]

116. Abbey, J.A.; Percival, D.; Abbey, L.; Asiedu, S.K.; Prithiviraj, B.; Schilder, A. Biofungicides as alternative to synthetic fungicide control of grey mould (Botrytis cinerea)—Prospects and challenges. Biocontrol Sci. Technol. 2019, 29, 241-262. [CrossRef]

117. Liu, J.; Sui, Y.; Wisniewski, M.; Droby, S.; Liu, Y. Review: Utilization of antagonistic yeasts tomanage postharvest fungal diseases of fruit. Int. J. Food Microbiol. 2013, 167, 153-160. [CrossRef] [PubMed]

118. Zamanizadeh, H.R.; Hatami, N.; Aminaee, M.M.; Rakhshandehroo, F. Application of biofungicides in control of damping disease off in greenhouse crops as a possible substitute to synthetic fungicides. Int. J. Environ. Sci. Technol. 2011, 8, 129-136. [CrossRef]

119. Nunes, C.A. Biological control of postharvest diseases of fruit. Eur. J. Plant Pathol. 2012, 133, $181-196$. [CrossRef]

120. Mari, M.; Di Francesco, A.; Bertolini, P. Control of fruit postharvest diseases: Old issues and innovative approaches. Stewart Postharvest Rev. 2014, 1, 1-4. [CrossRef]

121. Anuagasi, C.L.; Okigbo, R.N.; Anukwuorji, C.A.; Okereke, C.N. The impact of biofungicides on agricultural yields and food security in Africa. IJAT 2017, 13, 953-978.

122. Piombo, E.; Sela, N.; Wisniewski, M.; Hoffmann, M.; Gullino, M.L.; Allard, M.W.; Levin, E.; Spadaro, D.; Droby, S. Genome sequence, assembly and characterization of two Metschnikowia fructicola strains used as biocontrol agents of postharvest diseases. Front. Microbiol. 2018, 9, 593. [CrossRef]

123. Wisniewski, M.; Macarisin, D.; Droby, S. Challenges and opportunities for the commercialization of postharvest biocontrol. In Proceedings of the VI International Postharvest Symposium, Antalya, Turkey, 8-12 April 2009; International Society for Horticultural Science: Leuven, Belgium, 2010; Volume 877, pp. 1577-1582. [CrossRef]

124. Kurtzman, C.P.; Droby, S. Metschnikowia fructicola, a new ascosporic yeast with potential for biocontrol of postharvest fruit rots. Syst. Appl. Microbiol. 2001, 24, 395-399. [CrossRef] 
125. Viñas, I.; Usall, J.; Teixidó, N.; Sanchis, V. Biological control of major postharvest pathogens on apple with Candida sake. Int. J. Food Microbiol. 1998, 40, 9-16. [CrossRef]

126. Fravel, D.R.; Larkin, R.P. Availability and application of biocontrol products. In Biological and Cultural Tests for Control of Plant Diseases; Canaday, C.H., Ed.; APS Press: St. Paul, MN, USA, 1996; Volume 11, pp. 1-7.

127. Souza, J.R.B.; Kupper, K.C.; Augusto, F. In vivo investigation of the volatile metabolome of antiphytopathogenic yeast strains active against Penicillium digitatum using comprehensive two-dimensional gas chromatography and multivariate data analysis. Microchem. J. 2018, 141, 204-209. [CrossRef]

(C) 2019 by the authors. Licensee MDPI, Basel, Switzerland. This article is an open access article distributed under the terms and conditions of the Creative Commons Attribution (CC BY) license (http://creativecommons.org/licenses/by/4.0/). 